of Man, and Mr. Bennie's discovery of two ancient lakebottoms near Edinburgh containing an arctic fauna and flora.

The Second Part of the Annual Report is devoted to the work of the Palæontological Department of the service, and contains a summary of the chief changes, additions and rearrangements made during the year in the palæontological galleries under the charge of Messrs. Sharman and Newton.

The general collections in the Museum form the subject of Part iii., wherein Mr. Rudler reports the principal events in the history of the Museum during 1896. It is satisfactory to observe that the collections continue to attract thousands of visitors, and that not only the general public, but schools, natural history societies, students clubs, and individual students avail themselves of the admirable educational facilities afforded by the collections.

From what has here been said, it will be seen that the Annual Report of the Director-General of the Geological Survey is not a mere piece of dull statistics, but is an interesting and important contribution to science. It is a volume which will obviously be required in the library of every geologist, for it is crowded with observations which he will find nowhere else. Its publication as a separate work now places it within easy reach, and we trust that its sale will encourage Sir Archibald Geikie to continue the issue of as full a record in future years with perhaps, if the Stationery Office can be propitiated, diagrams illustrative of the more important facts described. In the meantime he and his able staff are to be congratulated on the appearance of so excellent a narrative of strenuous and successful labour.

\section{STYLES OF THE CALENDAR.}

$A T$ the approach of the end of a century, this subject naturally comes to the front ayain ; but it has lately been somewhat unexpectedly raised to special prominence by the suggested probability of one at least of the Oriental countries of Europe adopting the usage which, on the initiative of Rome in I 582, all the western nations gradually accepted, England (we say aclvisedly England not Britain, because Scotland adopted it before the union even of the crowns) being the last in 1752. America having been colonised by the western Europeans, and the United States having been still British colonies at the date last mentioned, the Gregorian style is universal in that continent. But eastern Europe, including Russia and all the nationalities of the Balkan peninsula, still adheres to the old Julian style; and this chiefly because the Christians of these countries belong to the Greek or Eastern Church, though it is difficult to see why this should restrain them from falling in with a change which has many conveniences, and would bring their dates into uniformity with those of the Latin, Teutonic, and Scandinavian nations-an object of increasing importance, as intercommunication is constantly becoming more frequent.

It is understood that for some time past, as the nineteenth century is drawing to its close, the question of a change has been discussed amongst the officials and astronomers of Russia; and that a plan was proposed to introduce it not by one operation, but gradually. Probably few persons amongst the general public reflect how essentially twofold the Gregorian alteration was; the object of making our calendar years correspond more accurately during the centuries with the tropical years of astronomers, so that the dates used should for all future time correspond with the equinoxes and other solar seasons, by no means implies the necessity of cancelling a number of days from the calendar so that these should correspond with what they were at some definite epoch in the past. The reason for this latter was purely ecclesiastical, the purpose being that, in

$$
\text { NO. [443, VOL. } 56]
$$

celebrating Easter, the full moon following the vernal equinox should be governed by one bearing the same date as it did at the time of the Council of Nicæa. This the Eastern Church appears to have thought of less consequence than did the Western; and, indeed, it cannot be proved that on this point the Council did more than decree, in opposition to the so-called Quartodecimans, that Easter Day should always be kept on a Sunday. However that be, when it was noticed that the vernal equinox (which in the time of Julius Cæsar fell on the $25^{\text {th }}$ of March, but in that of the Council A.D. 325, on the 2 Ist), the question was from time to time agitated at Rome of effecting a change in the Julian reckoning. In passing it may be mentioned that Cresar and Sosigenes the Alexandrian, who assisted him, were quite aware that the true length of the year was somewhat less than $365 \frac{1}{4}$ days ; the important point of the alteration of the calendar then carried out, was the abolition of the former cumbrous system of the Romans by combining a solar and lunar chronology with intercalary months, which were constantly falling into confusion, and the adoption of one wholly solar, the months being made artificial divisions, and it being thought that (the exact length of a year being not known) the regular introduction of an additional day every fourth year (making what we call a leap-year) would be quite sufficient for all practical purposes. Pope Sixtus IV. seriously took in hand the question of improving the Julian system, and in consequence of the great reputation of Regiomontanus (as he is commonly called from his birth-place, though his real name was Müller), who was making observations with his friend Walther at an observatory, the first ever made in Europe, erected by the latter at Nürnberg, sent for him to Rome to assist in this object, but, unfortunately, Müller died shortly after his arrival in 1476 , which was about three years after the birth of Copernicus. The scheme was therefore again delayed, and was finally executed under the authority of Gregory XIII. in 5582 . A century earlier it would have been adopted throughout western Christendom; as it was, the Protestant countries were slow to follow it, and some of the German States at first en. deavoured to make some modifications by using a true instead of a calendar full moon, which did not work well in practice, because the moon is not necessarily full on the same day in different localities. England adopted the Gregorian style in its entirety (already, as we have said, used in Scotland), chiefly at the instance of Lord Chesterfield in 1752 ; and long before the end of last century the same rule was observed over western Europe, no further alteration having been made since, though it has often been noticed that even the Gregorian year is not absolutely accurate.

A definite proposal is now being made in one of the smaller eastern States for the abandonment of the Julian reckoning still observed by them, and the adoption of the Gregorian style. In the Times of the IIth inst., Signor Cesare Tondini de Quarenghi informs English readers that he has drawn up a Bill at the request of the Bulgarian Prime Minister, M. Stoiloff, to be shortly laid before the Sobranye for the purpose of effecting this change in Bulgaria ; and he also states that he has been informed that Russia is desirous that this example should be thus set before being carried out in that country. How that may be, we are not in a position to know, but it is surely desirable (though even astronomers are not unanimous on the point) that the year should correspond on the whole, and as far as practicable, with its true length, whilst uniformity of usage throughout Christendom, would undoubtedly be a gain of convenience. We would fain hope that some international agreement might be come to by which, after the dropping of a leap-year in I 900 , its regular omission at the end of each period of I 28 years should be arranged. This would be a more 
accurate rule than the Gregorian; and as by either 2000 would be a leap-year, the difference would first show itself in 2028 , which, according to this arrangement, would not be a leap-year, whilst by the Gregorian scheme the next omitted leap-year would be 2 Ioo. The omission of a leap-year at the end of each period of 128 years was advocated, it may be mentioned, by Sir E. Beckett Denison (now Lord Grimthorpe) in his "Astronomy without Mathematics," and by the present writer in the "Companion to the British Almanac for I882." Its accuracy may easily be shown. It signifies having 3 I instead of 32 leap-years of 366 days in 128 years, and therefore 97 common years of 365 days. Now $365 \times$ $97+366 \times 3 \mathrm{I}=46,75 \mathrm{I}$, which, divided by $\mathrm{I} 28$, gives $365^{\circ} 2422$, the actual length of a tropical year to the fourth decimal. We cannot close without expressing a further wish that some agreement may hereafter be come to amongst Christian nations to celebrate Easter also according to an exclusively solar chronology, by observing it on the first or second Sunday in April. That, however, is independent of the plan now proposed in Bulgaria to abandon the Julian style of the calendar.

W. T. LYNN.

\section{GRANTS TO UNIVERSITY COLLEGES.}

I $\mathrm{N}$ accordance with an undertaking given by the 1 Chancellor of the Exchequer to a deputation which waited upon him at the end of 1895 , with reference to increased aid from public funds for the University colleges, three gentlemen, viz. Mr. T. H. Warren (President of Magdalen College, Oxford), Prof. D. G. Liveing, F.R.S. and Mr.Robert Chalmers, of the Treasury, were appointed in March 1896 to visit the colleges sharing in the grant made to universities and colleges in Great Britain, and to investigate the character and quality of university work done, as well as to inquire generally into the position which each college occupied both financially and in other respects The visits were concluded by the end of last year, and the report came before the Lords of the Treasury about two months ago. The results of the inquiry showed the Chancellor of the Exchequer that a case had been made out for asking Parliament to increase the sum to the colleges sharing in the grant; he therefore recommended that the total grant to the colleges should be increased from $15,000 l$. to $25,000 l$. as from April $\mathrm{r}, \mathrm{1} 897$. The question of the apportionment of this total sum was thereupon referred to a special Committee, whose recommendations, as will be seen from the subjoined Treasury Minute, have been accepted :-

My Lords read the report of the 2oth ult. from the Committee appointed by the Treasury Minute of April 5 last to advise this Board in the matter of the apportionment of the increased sum of $\mathbf{2 5}, 000$ l. which Parliament has been asked to vote in the current financial year for University colleges in Great Britain.

My Lords accept the apportionment which the Committee propose, viz. :-

The Owens College, Manchester

$\cdots+\cdots=300$

Mason Coll $\begin{array}{lllll} & & & & 3000\end{array}$

$\begin{array}{lllll}\text { Mason College, Birmingham } & \ldots & \ldots & \ldots & 2700\end{array}$

$\begin{array}{lllll} & \cdots & \cdots & \cdots & 2200\end{array}$

$\begin{array}{lllll} & & & \end{array}$

$\begin{array}{llllll}\text { Durham College of Science } & \ldots & \ldots & \ldots & 2200\end{array}$

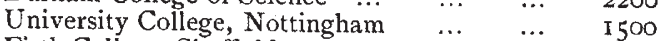

$\begin{array}{lllll}\text { Firth College, Sheffield } & \ldots & \ldots & \ldots & \text { I } 300\end{array}$

$\begin{array}{lllll}\text { University College, Bristol } & \ldots & \ldots & \ldots & \text { 1 } \\ & \ldots & \ldots & \text { I } 200\end{array}$

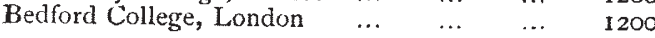

University College, Dundee ...

$$
\text { Total } \quad \ldots \quad \ldots \quad \ldots \longdiv { £ 2 5 , 0 0 0 }
$$

In deference to the express recommendation of the Com. mittee, my Lords have consented to grant to the Owens College
Manchester, a sum in excess of the maximum of 3000 . specified in the Board's Minute of April 5, 1897. They desire, however, to make it clear that this increase is made solely in recognition of the pre-eminence of the Owens College, and must not be construed as a precedent for increasing the grant of any other college beyond the normal maximum.

My Lords take note of the term of the Committee's report with regard to the Dundee College. In acceding to the Com. mittee's recommendation that "for the present" the college should receive 1000 l. a year, my Lords are guided, as they understand the Committee to have been guided, by the exceptional position in which the college is now placed with regard to St. Andrews University. My Lords, however, are of opinion that, when the relations between the University and the college are settled, this matter should be subject to reconsideration ; and they must not be understood to admit the claim of the college to share permanentiy in the grant to University colleges.

The Board accept, so far as they are concerned, the recommendation that, with the exception of Dundee College, the above allocation should be settled for a term of five years from April I, I897. They also agree that before the end of such term a further inspection should be made on behalf of the Treasury.

My Lords will communicate to the colleges concerned the Committee's recommendation in paragraph 6 of their report that, in certain cases, three-fourths of the additions to the several grants should be devoted to staff purposes.

The future inspection, as recommended by the Committee, should extend to the University Extension colleges at Reading and Exeter, as also to the Hartley Institute at Southampton, and to any other college which, being located in a populous district, may claim to be treated as a fully-equipped college in arts and science.

The Chancellor of the Exchequer invites the Board to consider the qualifications, other than educational, which should be required from a college seeking to share in the grant in future. The Chancellor of the Exchequer submits to the Board that public money should not be contributed to a college which is still in the experimental stage or which has not yet succeeded, though fully equipped, in attracting a considerable number of students in arts and science. He therefore recommends that the financial conditions of participation should be-(I) A total local income for arts and science of at least $4000 l$. a year; and (2) a receipt from fees in the same subjects of at least $1500 l$. a year.

My Lords approve. It only remains for them to record their appreciation of the valuable services which the Committee has been so good as to render to this Board in considering the claims of the respective colleges.

\section{HONOURS FOR MEN OF SCIENCE.}

THE honours list issued on Tuesday in connection with the Diamond Jubilee contains the names of a number of men of science upon whom her Majesty has been pleased to confer distinctions.

Dealing first with Fellows of the Royal Society, Mr. Crookes and Dr. Gowers receive knighthoods. In the order of the Bath, Mr. Wolfe Barry, President of the Institution of Civil Engineers, Dr. Frankland, Foreign Secretary of the Royal Society, Dr. Huggins, Mr. Norman Lockyer, Director of the Solar Physics Observatory, Dr. 'Thorne Thorne, Principal Medical Officer to theLocal Government Board, and (naval promotion) Admiral Wharton, Hydrographer of the Admiralty, are appointed K.C.B.

Mr. Christie, Astronomer Royal, and Mr. Niven, Director of Studies at the Royal Naval College, are appointed C.B.

In the Order of the Star of India, Sir Joseph Hooker and Lieut.-General Strachey are promoted to the grade of G.C.S.I.

In addition to the foregoing, Baronetcies are conferred upon Sir Wm. MacCormac, President of the Royal College of Surgeons; Mr. Wilks, President of the Royal College of Physicians; and Mr. Thomas Smith, SurgeonExtraordinary to her Majesty. Mr. Durston, Engineerin-Chief to the Navy, is made a K.C.B., and knighthoods are conferred upon Mr. A. R. Binnie, the Engineer to the. London County Council, and Dr. Felix Semon.

$$
\text { NO. } \left.1443 \text {, VOL. } 5 t^{7}\right]
$$

